\title{
African tourist art as tradition and product of the postcolonial exotic
}

\author{
Bernadette van Haute \\ University of South Africa
}

vhautbmr@unisa.ac.za

\begin{abstract}
Figurative art made in Central and West Africa for the global market is a form of tourist art - a category that has been plagued in art historical research by misconstrued concepts such as the authenticity of traditional/precolonial art. Following its categorisation as a commodity, studies focused on the decontextualisation of the object, thus marginalising the producing culture. In this article I investigate the role of the artist in preserving tradition and the role of the trader who, as cultural broker, exoticises the object. Since it can be argued that these are acts of decolonising, African tourist art can be regarded as a product of the postcolonial exotic, as defined by Graham Huggan (2001). Accepting the inescapability of postcoloniality, tourist art can be repositioned as a successful attempt to preserve and promote African cultural traditions and identity in the new era.
\end{abstract}

Keywords: Africa; art; art traders; commoditisation; cultural tradition; exoticism; marginalisation; postcolonial; producers; resistance; tourist art

\section{Introduction}

The object of this study is contemporary figurative art made by West and Central Africans and offered for sale at markets in South Africa. These masks and statues,

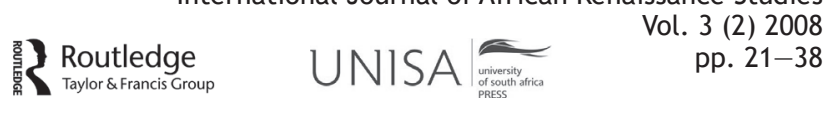


produced expressly for the global market, belong to the category of tourist art because they are copies or replicas that imitate traditional forms of art (Steiner 1994, 35). This article aims to summarise the criticism levelled against the terminology used within this field of art historical study, and discusses the commodification of postcolonial African art which led to a marginalisation of the producers. Seeking to re-assess the agency of both the artist and the trader, I adopt Huggan's notion of the postcolonial exotic which, he claims, marks the intersection between postcolonialism that posits itself as anticolonial, and postcoloniality, which is more closely tied to the global market (Huggan 2001, 26). If African tourist art is accepted as operating as an oppositional system of postcolonial resistance, it is necessary to reconsider the significance of the artist as a guardian of cultural traditions and of the trader as co-author in the decolonisation of African tourist art. With reference to my field research, particular attention is paid to the role of the African trader as a cultural broker who exoticises tourist art to make its cultural difference acceptable to the global market. By viewing tourist art not merely as a commodity on the global market but also as a response to the quest for postcolonial resistance, it is possible to reposition tourist art as a successful strategy of preserving tradition in the era of global consumerism.

Over the years, various attempts have been made to define, classify and interpret African tourist art. ${ }^{1}$ The most controversial issues in the discourse have been the concepts of traditional African art and authenticity.

\section{Tourist art versus traditional African art}

Tourist art in Africa is art produced by Africans for an external market, and is characterised by stylistic hybridity (Phillips and Steiner 1999, 9). As such, it is the opposite of 'traditional' African art which was supposedly already made in precolonial times by Africans for use in the local community (Lawal 1990, 1) and believed to display cultural or ethnic purity. ${ }^{2}$ In fact, this conception of traditional African art is, in itself, already flawed. Contrary to popular belief, tourist art came into being very soon after the first contact between the coloniser and the colonised. As part of their imperial strategy, colonial powers deliberately suppressed precolonial cultures in a policy of assimilation, aimed at the suppression of difference (Griffiths 2006, 167). In the process, the colonisers attempted to wipe out distinctive collectivities (ibid) and yet, at the same time, they contributed to the formation of new art forms. An example is the Mangbetu art of Northeastern Zaire (present-day Democratic Republic of the Congo). ${ }^{3}$ According to Schildkrout $(1999,197)$, Mangbetu art 'emerged as a genre in the early colonial period as a product of the interaction between African artists and their African and European patrons'. Western demand for this art created not only a new market, but also a partially invented tradition that served as its ideational basis and supportive text. Its meaning was fabricated through the communication between producers and consumers 'in accordance with their perceptions of each other's needs, desires and intentions' (Schildkrout 1999, 203-204). ${ }^{4}$ The producer had to adapt creatively to this new situation and invented what 
later became stereotypes that were not representative of a 'real' or 'pure' tradition. The fact that adaptation happened so early ${ }^{5}$ and quickly implies that maybe more African art forms that were thought by Westerners to be traditional, were a material effect of European colonialism and hence already hybridised.

\section{The concept of authenticity}

Traditional African art is, per se, authentic African art. The concept of authenticity was developed essentially to create a canon of African art in which so-called traditional art is regarded as the highest form of aesthetic expression. It has been claimed that the authenticity of an object depends on its use by the same society that produced it before the advent of colonialism, on its unchanged stylistic appearance, on its existence in an 'ethnographic present', and on the anonymity of its maker (Kasfir 1999b, 90-94). ${ }^{6}$ The fallacy of authenticity is easily demonstrated in the light of the discourse on cultural appropriation and contamination. Firstly, as discussed above, there is evidence that some so-called canonical African art was created within a colonial and postcolonial context for foreign collectors (Kasfir 1999b, 90). Secondly, style and iconography were not restricted to highly localised ethnic groups (Steiner 1994, 7) and, in certain cases, were influenced by the colonial presence. Where transformations took place, it was Western taste that dictated what was authentic art (Kasfir 1999b, 91). The fiction of a 'timeless past' art led to the myth of an ethnographic present where radical changes do not intrude. ' 'Just as casting African art in an ambiguous ethnographic present denies it history', says Kasfir (ibid, 94), 'insistence on the anonymity of African artists denies it individuality'. To erase identity is to increase mystery. By creating a cultural distance between maker and collector, the Western connoisseur could reinvent the African artefact and transform it into art (ibid).

This Western concept of authenticity gave rise to 'the notion that authentic Africans, and by extension authentic objects of African art, no longer exist' (Steiner 1994, 104). It also evidently led to the condemnation of tourist art as the most inauthentic form of African art. ${ }^{8}$ Tourist art was seen to be contaminated by colonial contact, and to illustrate the cultural decay following the loss of a precolonial world of order and control - an idealisation for Europeans and Africans alike (Kasfir 1999b, 107). Because the notion of authenticity rests on the assumption of an idealised precolonial past, I accept Kasfir's suggestion 'to leave behind a rather myopic classificatory system based so heavily on an Africa of the mind' (ibid, 110). After all, authenticity is always a variable (Graburn 1999, 352), constructed by whoever decides to pluck the object from its environment, to reclassify it (as art) and infuse it with meaning (Lee 1999, 281). This position is in contrast to Jules-Rosette $(2002,118)$, who maintains that 'the debate over authenticity is critical to discussions of tourist art'. In my opinion, it makes more sense to abandon the authenticity paradigm lest 'we perpetuate colonialist practice' (Cohodas 1999, 161). 


\section{Commodification}

In an attempt to avoid imposing 'primitivising judgements of authenticity' (ibid, 160), attention shifted to the role of the consumer. In postcolonial times, the central premises were the commodification of the artwork and the dominance of an international art market (Kasfir 1999a, 14). ${ }^{9}$ Following this trend, tourist art has been categorised as a commodity made by a producer for a consumer in a global system of exchange. The commoditisation of African art involves the 'diversion of commodities from their predestined paths' (Appadurai 2006, 417), thus turning utilitarian objects into artworks. The value of the African artefact is enhanced by placing it in an unlikely context, and this enhancement of value underlies its purchase and display (ibid, 419). ${ }^{10}$ Once removed from its original context, the object is believed to have lost its meaning, thus allowing the Western consumer to create meaning for African art rather than the cultures and artists who produce it (Kasfir 1999b, 98). The object acquires new meaning through its display in the home as a fashionable piece of decoration. Or it becomes a souvenir for the tourist, commemorating an (expensive) adventure and immortalising the exotic 'other' who exists primarily in the tourist's own imagination (Lee 1999, 270-271). Once the object has reached the Western context, it is recontextualised and denied its use value. This very lack of practical function actually heightens the object's aesthetic value and allows its recognition as an artwork (Steiner 1994, 159-161).

In fact, its categorisation as a commodity nearly paralysed the art historical study of African tourist art. Studies on the consumption of African art in the West have focused on the implications of the displacement or decontextualisation of the object, questioning its meaning in its new milieu (ibid, 12-13). Kasfir (1999c, 83) criticised this 'Western tendency to see the meaning of the souvenir for its recipient as if that were its only meaning'. Because the artwork forms part of cultural practice, it may be more useful to restore the agency of both the artist and the dealer as creative persons who give expression to their cultural values. I aim to consider this option within the framework of the postcolonial exotic, as expounded by Huggan (2001).

\section{The postcolonial exotic}

While the aesthetic value of African tourist art depends on its decontextualisation, it actually resides in the exoticism of the culturally different object. According to Huggan (2001, ix), exoticism 'may be understood conventionally as an aestheticising process through which the cultural other is translated, relayed back through the familiar'. It 'describes a political as much as an aesthetic practice', even though this politics is often hidden or disguised by the exotic spectacle and the curiosity it arouses (ibid, 14). Exoticism also hides the power relations behind essentialist labelling of marginalised ethnic groups, allowing the dominant culture to attribute aesthetic value to the margins. Cultural difference is fetishised through the process of cultural translation, so that 'the marginalised other can be apprehended and described in familiar terms' (ibid, 24). 
The cultural translator is a culture broker mediating the global trade in exotic goods (ibid, 26). In the case of the African tourist art market, the cultural broker is the trader or middleman. He knows that difference is appreciated, but only in the terms of the beholder. Hence he translates diversity and gives it 'a reassuringly familiar aesthetic cast'. This process, Huggan (ibid, 27) argues, 'bespeaks a new-found form of the exotic' that he calls the 'postcolonial exotic'.

According to Huggan (ibid, 5), the postcolonial field of production occupies a site of struggle between contending 'regimes of value'. These two regimes of value can be referred to by the terms 'postcolonialism' and 'postcoloniality'. He defines postcolonialism as the oppositional system of postcolonial resistance, and postcoloniality as the profit-driven system of the transnational culture of industries and global trade (ibid, 264). The irresolvable struggle between these competing regimes of value plays itself out over the value of cultural difference. While apparently conflicting, these two 'regimes of value are mutually entangled' (ibid, 6). Postcolonialism is bound up with postcoloniality, because there is an 'inextricable connection between the production of the postcolonial and the globalisation of consumer society' (ibid, 263). And this is where he places the postcolonial exotic: it 'represents the interface between these two apparently incompatible systems', namely, postcolonialism and postcoloniality. 'Arising from the clash between these two contending systems is a series of exotically hybridised ... products' (ibid, 263-264).

Whereas African tourist art may at first appear to be 'a sign of the durability of colonial fantasy and of its profitability', Huggan (2001, 263-264) identifies it as an outright commercial product of the postcolonial exotic. Distinctively African in appearance, it is clearly geared to the global market. Hence it is 'caught between the demands of a transnational consumer public and the need to decolonise cultural production in a post-independence age' (ibid). While tourist art is an effect of commodification, the success of these postcolonial products is not merely a function of their viability as commodities on the global market (ibid, vii). Instead, their success also depends on their capacity to respond to the quest for postcolonial resistance. Although I would not go so far as to maintain that African tourist art has an explicitly political agenda, I would argue that the intensified production and marketing of traditional art forms is indeed sustained by a desire to decolonise African cultural production in the post-independence age.

\section{Decolonising African tourist art}

One of the strategies to decolonise African art was to return to and make use of tradition as an ideology that aims at collective creativity. According to Makang (1997, 336), a living tradition is 'neither a repetition of practices and customs of the past, nor a dream of "the origin" or of a "lost paradise", but is meant to provide a utopian model of action, a mobilizing ideal'. He maintains (ibid): 
Tradition as an ideology of society or as a utopia aims at enlightening African people in their striving for adaptation to new material conditions of the present world, with their selfdetermination and a better quality of their humanity as their common purpose. By appealing to the praxis and wisdom of our African foreparents, we do not mean to repeat them, but we mean to make use of this praxis and wisdom as interpretative tools to enlighten present generations of Africans.

Tradition was also used by African nation-states at the dawn of their independence to foster a cultural nationalism that could contribute to the formation of a national identity. An example of this is the ideology of authenticity developed in Zaire by the Popular Movement of Revolution (MPR) of President Mobutu Sese Seko, which aimed to emphasise African cultural difference from the West (ibid, 330). Another example is the campaign launched in Côte d'Ivoire in the late 1980s to foster national unity in the face of internal ethnic factionalism and tension (Steiner 1994, 97). Because the Ivoirian state faced a weakened economy, the postcolonial government campaigned for nationalism through the preservation of local artistic traditions. As an indigenous product encapsulating the traditional arts of Côte d'Ivoire, the mask was chosen as a sacred icon and symbol of national identity and character (ibid, 88, 95). Steiner (ibid, 95-96) argues that the 'return to traditionalism and the recreation of a "primitivist" aesthetic' were a direct result of the nation's financial collapse and served both national integration and international economic success. On the one hand, by elevating the symbolism of the mask to a single, national icon, the state aimed to reconcile growing ethnic divisions. On the other, in the search for a new source of foreign income, the mask was thought to 'fuel the Western imagination through its mystery and exotic appeal' (ibid, 96).

Whereas the return to a collective cultural tradition may have largely failed as a nationalist strategy in Africa, ${ }^{11}$ it proved far more successful, both as an economic strategy and as an oppositional system of postcolonial resistance, in the international art market. The continuation or recreation of an ethnic aesthetic - often from an imagined precolonial past - was a conscious attempt at reclaiming African art from the Western connoisseur. Both the artist and the trader played a role in restoring African art in Africa and both continue to preserve it.

\section{The artist as decoloniser}

In order to establish the ways in which the artist is capable of decolonising African tourist art it is necessary to first consider his working circumstances. The producer of African tourist art is usually a male artist working on his own, or a group of artists working in an old-fashioned kin-based workshop or cooperative (Kasfir 1999a, 105). In the well-known sculpture-producing regions of West and Central Africa, artists making traditional genres such as masks and figurines often work for both the local community and the global market. The most accomplished sculptors receive the most prestigious commissions both from local societies and foreign dealers, while the least technically competent carvers supply the tourist market (ibid, 107). For the latter, art making is a 
livelihood, a 'necessity for life, a strategy promoting financial empowerment in deprived rural communities' (Arnold 2008, 26). It is the harsh realities of life - what Arnold (ibid, 30) calls the 'death-destruction-disease-despair syndrome' - in modern Africa that have contributed to the level of commodification of African tourist art. Moreover, since there are many more mediocre carvers than in the past, commodification has lowered the overall quality of African carving (Kasfir 1999a, 107).

Since the artist simply replicates traditional art forms to earn a living, his art making is not considered a creative act of self-expression (Kasfir 1999b, 96). These African artists are actively discouraged from being creative simply because novel, strange objects are difficult to sell (Schildkrout 1999, 204). Moreover, they cannot introduce change for fear of being labelled incompetent in matching the traditional paradigm (Nevadomsky 2005, 77). Artworks are thus characterised by imitation or repetition of forms in response to market forces and as a result of the Western notion of authenticity - a notion that has fixed African art in stereotypical forms (Steiner 1994, 108). In those instances where the precolonial prototype has disappeared, artists may even resort to books as sources of inspiration. For example, in the mid-1990s Benin brass casters 'relied on the picture texts of Pitt-Rivers (1900), Fagg (1963) and Dark (1973)' (Nevadomsky 2005, 77) for the design of objects.

The above describes how the African producer of tourist art is perceived through the lens of Western aesthetics. From a different perspective, however, it could be argued that the artist wants to recover pride in his/her African heritage. Even though - or perhaps because - art-making is a livelihood, the artist working at ground level continues a sculptural tradition inherited from the past, ensuring a sustained social relevance at a local level (Picton 2002, 331). ${ }^{12}$ Despite some changes in technology and style - a development that is interrelated with the international commodity market (Nevadomsky 2005, 68) ) $^{13}$ - the artist adheres to a local tradition that characterises the object as specifically Yoruba, Senufo or Bakuba. These objects express a specific local aesthetic and are shaped by indigenous praxis, wisdom and ideology. One could thus claim that it is pride in a sustained cultural existence that drives the production of art for the tourist market. This production reflects cultural continuity and adaptation in the face of enormous pressures to 'assimilate or otherwise fade away' (Ettawageshik 1999, 29) ${ }^{14}$ In this instance, adherence to a collective cultural tradition not only enables the artist to recuperate those aspects that have value in indigenous systems of thought, but his cultural 'resilience in and through the local and specific' (Griffiths 2006, 168) also proves very successful as an economic strategy to sell art in the international market. What the tourist demands is, indeed, an artwork that exudes a 'primitive' aura and looks suitably African and exotic. 


\section{The trader and the postcolonial exotic}

The producer of African tourist art is, however, not in direct contact with the global consumer: distribution is the domain of the African trader who acts as the middleman. It is the African trader who makes a selection and ultimately decides what appears on the market and how. One could even say that it is the trader who is the driving force behind the continued production of tourist art across the African continent. ${ }^{15}$ In his study African art in transit (1994), Steiner focuses on the African trader as a cultural broker and explains the implications of the elaborate process of cross-cultural information exchange that facilitates commoditisation. Since Steiner conducted his field research in Côte d'Ivoire in the late 1980s, I have visited several art markets in South Africa to assess the current situation. A first significant development is the fact that African art markets have proliferated both in volume (Figures 1 and 2) and number in the past decade. This can be attributed to a number of political and economic factors - a weakened economy experienced in Central and West African states is but one of the contributing factors - but the major driving force is global trade. Because South Africa is a popular tourist destination, foreign traders flock to its markets to sell their wares. I interviewed African traders mostly from West Africa. Although their methods, appearance and behaviour largely match those described by Steiner, their motives need to be re-assessed in terms of the postcolonial exotic.

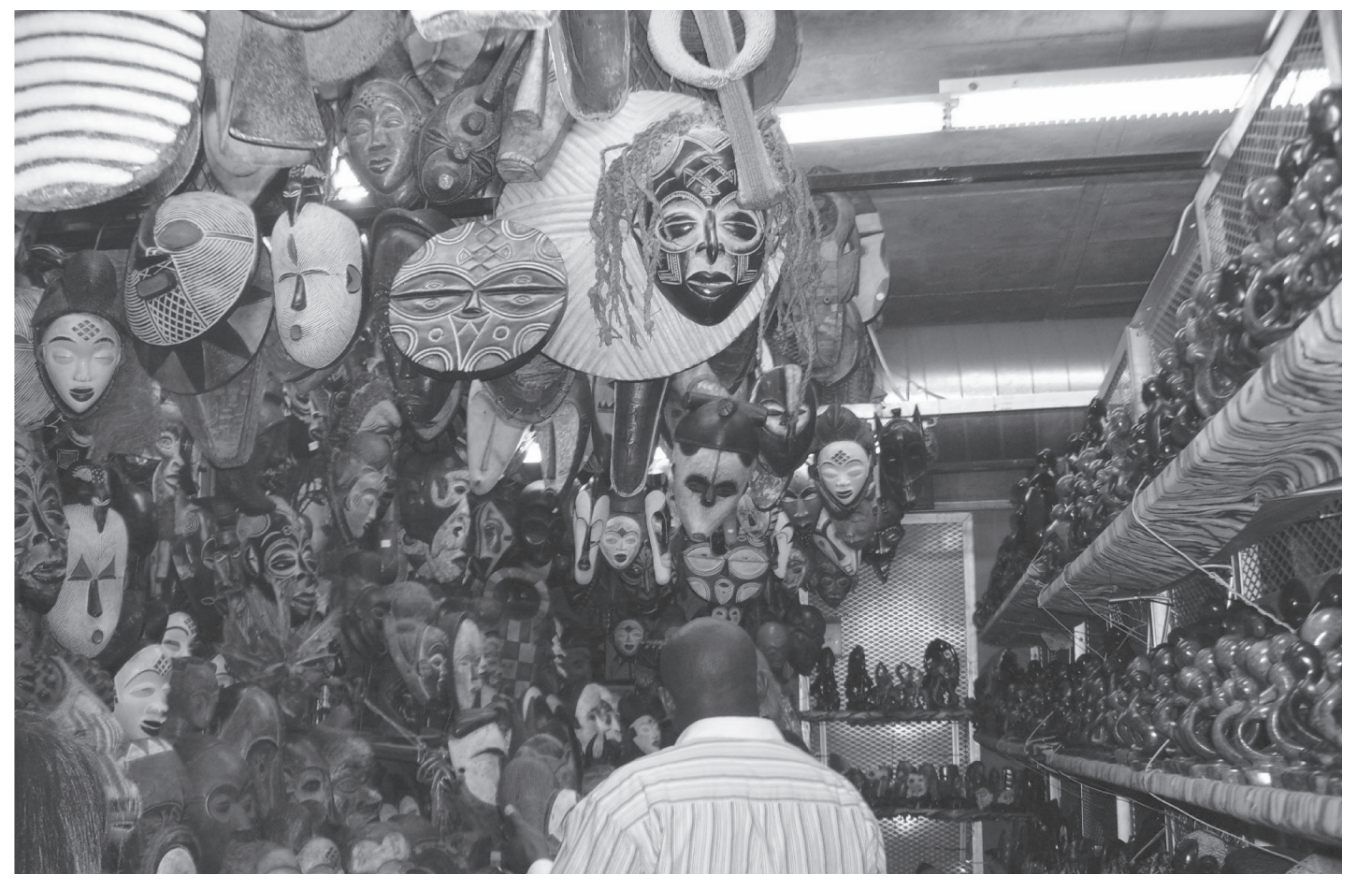

Figure 1: Stall 41 at the African Craft Market, Rosebank in Johannesburg, run by Ismaila Njimbouom (23 April 2008). Hundreds of objects are crammed into a narrow space - some are even suspended from the ceiling. 


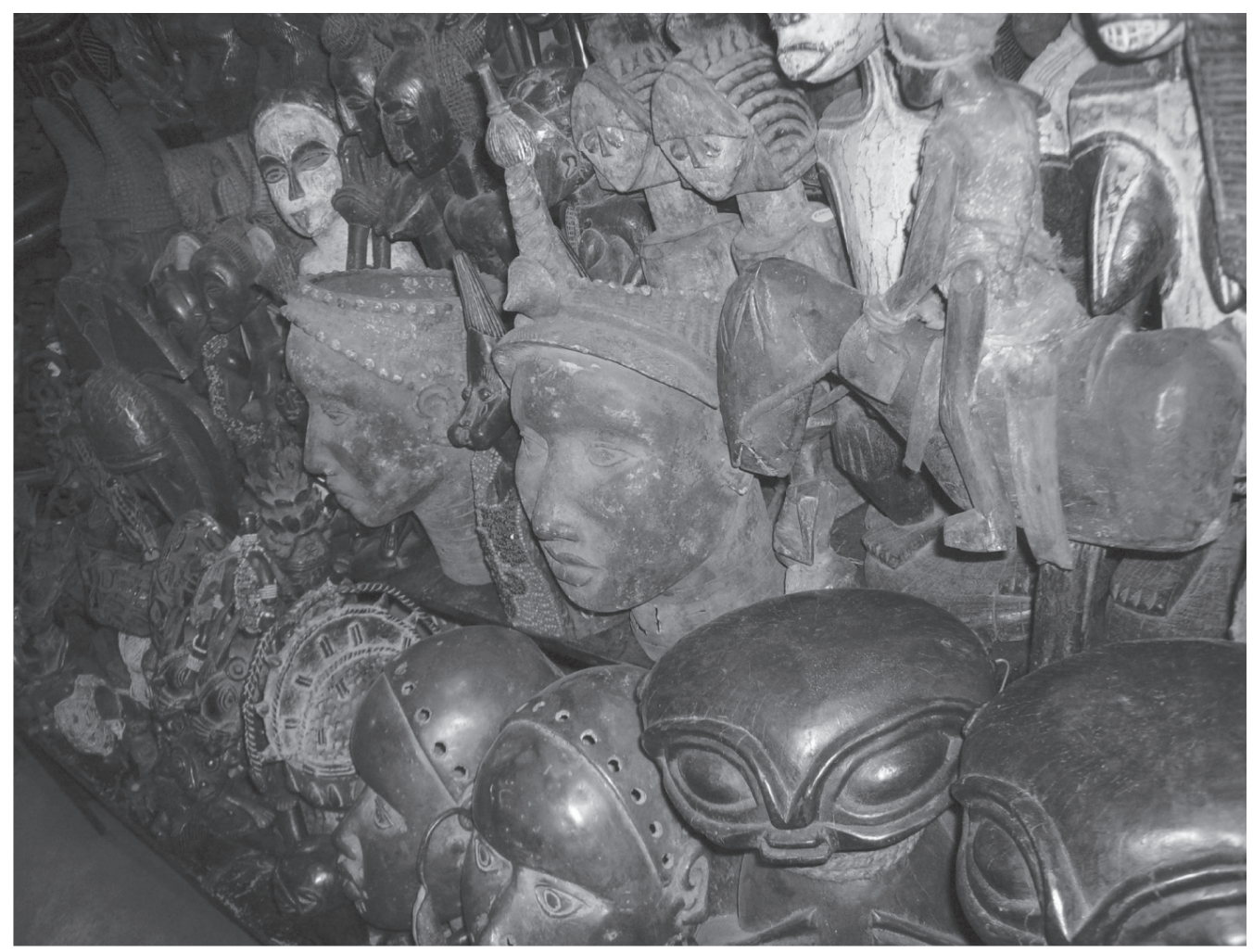

Figure 2: Another view of Stall 41, African Craft Market, Rosebank in Johannesburg, run by Ismaila Njimbouom (23 April 2008).

One such dealer trading at Hatfield Market in Pretoria is Ervicks Ngatat, who identified himself as a lesser chief in the Bamileke village of Tonga, in Cameroon. ${ }^{16} \mathrm{He}$ informed me that he sells African art only in South Africa and travels three to four times per year to West and Central Africa to purchase stock which is transported by air. He buys the items from people living in small villages, who make the objects according to traditional norms (i.e. without any additions). Objects that are in use in the villages are not offered for sale. Ngatat maintains that cultural customs such as ceremonies accompanying marriages, funerals and initiation rituals are still practised in these villages. This explains the continued production of objects used in such ceremonies. With a subsistence economy in place, the people in the villages are very poor and the sale of artworks supplies them with extra income. Ngatat's statements thus confirm the continuation of a situation observed by Kasfir: that of the masks and figures produced in West and Central Africa, some are 'still intended for local use and others for a global market' (Kasfir 1999a, 16).

Although Ngatat identified himself as Bamileke, it was more important to him to emphasise his pan-African identity and underscore his Africanness by wearing the traditional flowing robes of African Muslims. ${ }^{17}$ It is this very Africanness, this 
spectacle of cultural otherness cloaked in mystery, that drives the tourist market. The African trader capitalises on his cultural otherness and perpetuates the tourist's naïve assumptions of an exotic Africa. To further satisfy the tourist's expectations, the African art merchant has appropriated the Western notion of authenticity. Through experience he has learned to distinguish the criteria underlying this concept of authenticity that governs his commercial activities (Steiner 1994, 131). In the first place, Ngatat buys and sells only traditional-looking artefacts that are representative of a primitivist aesthetic. He markets his goods by manipulating them in three ways; these ways are identified by Steiner (ibid) as the presentation, description and alteration of the objects.
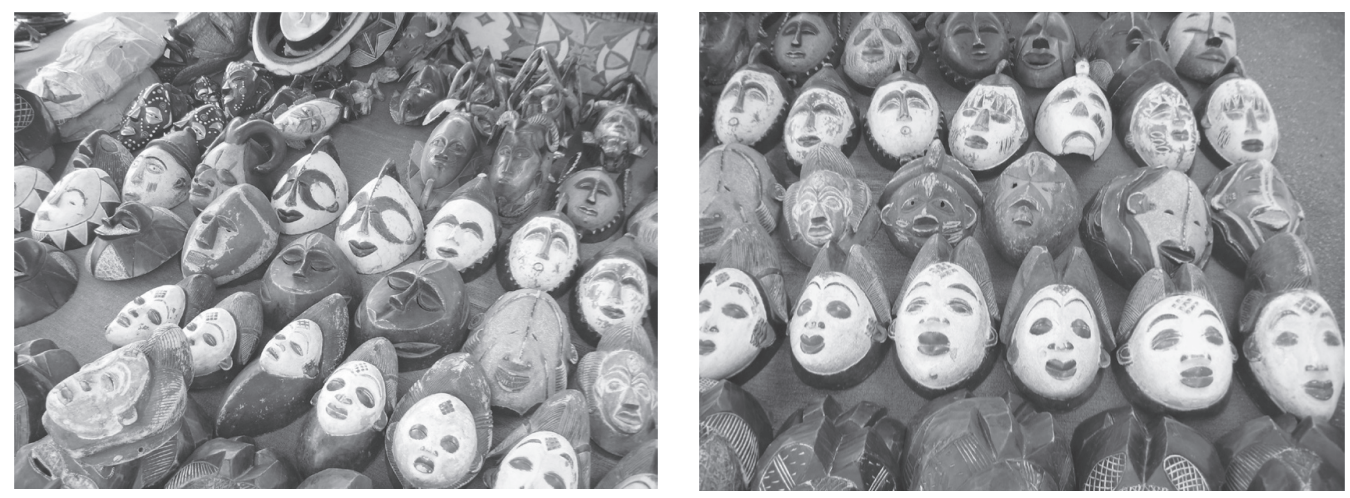

Figures 3 and 4: View of the left-hand (Figure 3) and right-hand (Figure 4) side of the 'mask stall' of Ervicks Ngatat, Hatfield Market, Pretoria (9 March 2008). In the top right-hand corner of Figure 3 appear some brightly coloured Guru masks (Côte d'Ivoire). In Figure 4, the bottom row consists of Punu masks (Gabon) whose white faces, red eyes and red lips are said by Ngatat to denote feminine beauty in Gabon.

As far as presentation is concerned, Ngatat displays his wares at Hatfield Market in two different stalls. In one stall, rows of African masks cram the floor space, although every row consists of a different type of mask coming from Côte d'Ivoire, Cameroon, Gabon, the Democratic Republic of Congo (DRC) or the Congo (Figures 3 and 4). The other stall is quite unusual in that an enormous variety of statues are bundled together, according to height, in an impressive display of Africanness (Figures 5 and 6). 

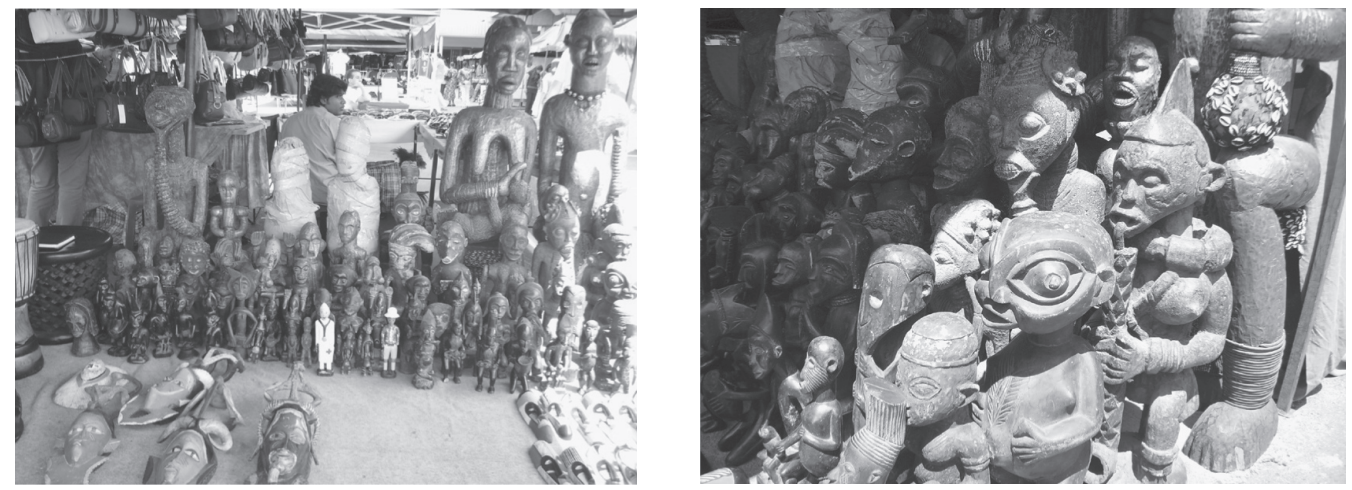

Figures 5 and 6: View of the right-hand side of Ervicks Ngatat's 'statue stall', Hatfield Market, Pretoria (9 March 2008). The statues are arranged according to size. Figure 6 shows a detail from the right.

A separate, more spacious arrangement of more expensive Ife and Benin 'bronzes' fills the other corner of the stall (Figure 7), while some 'antique works' occupy pride of place in the front (Figure 8).
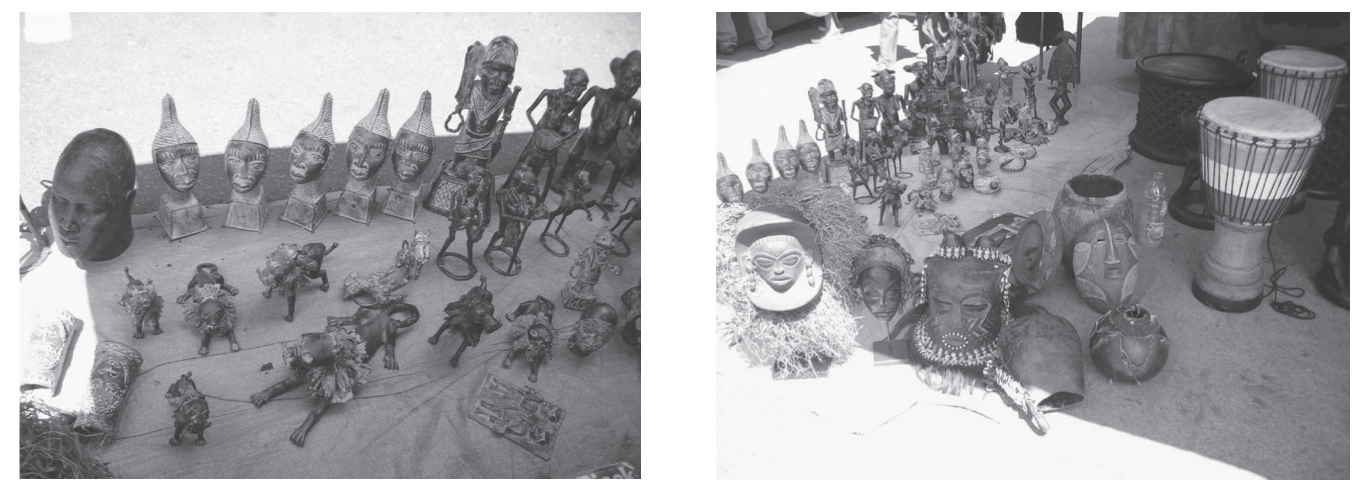

Figures 7 and 8: View of the left-hand corner of Ervicks Ngatat's 'statue stall', Hatfield Market, Pretoria (9 March 2008). The Ife and Benin 'bronzes' (Nigeria) (Figure 7) are spaciously arranged. Note the costly 'antiques' in the foreground in Figure 8.

Ngatat's presentation of the objects is thus clearly in line with the Western notion of authenticity. The mass-produced copies are stacked together in a random manner, while the display of the costly 'antiques' is spacious and prominent - the Tchokwe masks (DRC) are even mounted on gallery-like pedestals (Figure 9). When I questioned the authenticity of one of his antiques, Ngatat was quick to reassure me, hauling out a tattered copy of Laure Meyer's Black Africa and Afrique noire by Leiris and Delange, and pointing out a photograph of a similar object in a (Western) museum. This demonstrates some dependence on Western authors (in the African tourist industry) to discover the inherent value of an African art object (Steiner 1994, 102) and sanction its so-called authenticity. 


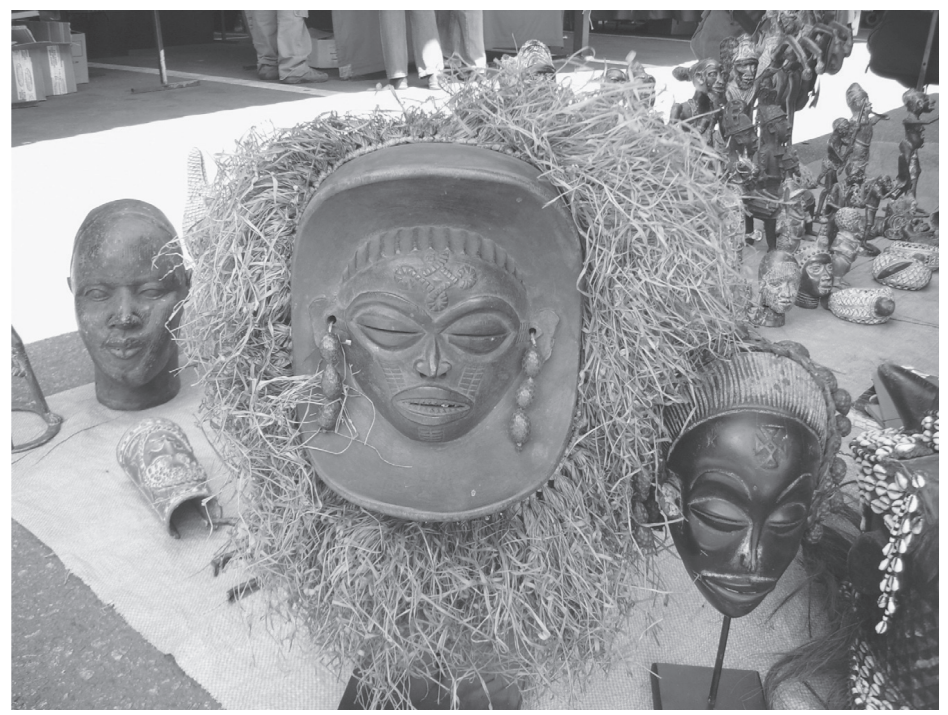

Figure 9: Detail of Figure 8, with Tchokwe masks (DRC) mounted on gallery-like pedestals.

Another antique on display was a visibly repaired 'medicine pot' (Congo) (Figure 10). The repair on this pot, which was singled out by Ngatat as proof of its age and ritual use, illustrates the practice of altering objects to give them an authentic 'look' (Steiner 1994, 140). ${ }^{18}$ Another tactic deployed by the trader is flattery: he praises the client for being able to distinguish an ancien (old) from a recent copy. This leaves the client with the impression of having discovered something valuable, and obviously increases the trader's chances of a sale.

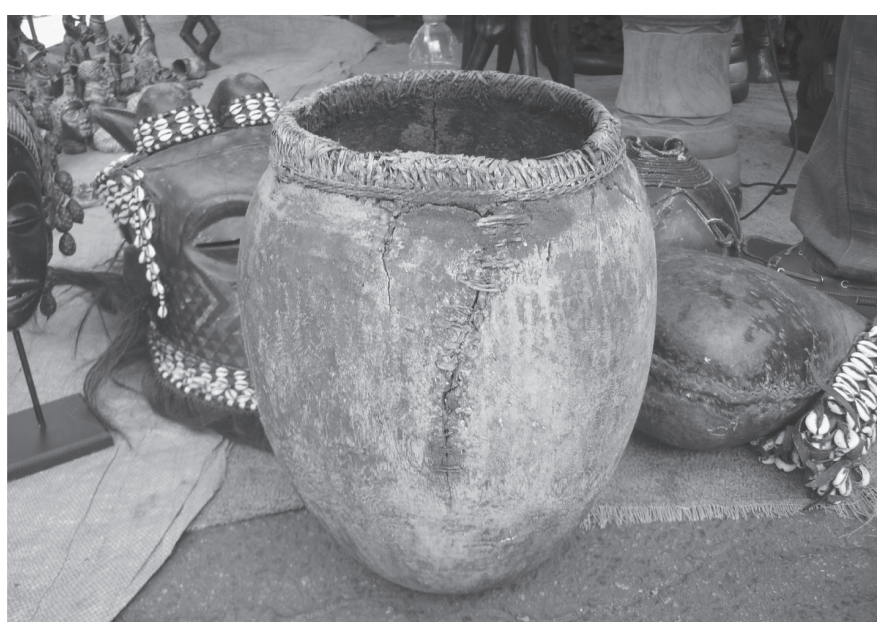

Figure 10: Detail of Figure 8, showing the 'medicine pot' (Congo) with its repair work. 
The third way in which objects are manipulated is description: the trader will describe or create a narrative around the object in an attempt to authenticate it (Kasfir 1999a, 111). Ngatat confidently recounted the origin of each item (country and ethnic group) and offered an explanation of the object's cultural meaning and use in its traditional context (see Figure 4). Some of his explanations were, as Steiner $(1994,139)$ put it, 'nothing more than stories which are invented purely to entertain the buyer.' The information was quite simply constructed to satisfy Western taste and expectations. Yet in doing so, the trader reinvents the piece (Kasfir 1999a, 111). Thus, the middlemen are not merely moving goods through the world economic system, but are also 'exchanging information - mediating, modifying, and commenting on a broad spectrum of cultural knowledge' (Steiner 1994, 2).

The trader realises the need to support and build on the artist's adherence to a collective cultural tradition. As a cultural broker, someone who is both a 'native informant' for his original African culture and a global migrant conversant with metropolitan cultural taste (Huggan 2001, 26-27), the trader mediates between two different cultural groups, interpreting and capitalising on the cultural values and desires of both worlds (Steiner 1994, 14, 155). Beyond simply mediating, the trader exoticises the object in order to make its cultural difference acceptable to the global market. The object is given 'a reassuringly familiar aesthetic cast' (Huggan 2001,27) which, in my view, is achieved in two ways. In the first place, the trader makes sure he selects only those objects which are perceived to be representative of the great precolonial African art traditions. While they embody cultural otherness, these objects are familiar as emulations of 'primitive' forms and styles. Secondly, the trader exoticises the object by manipulating and encoding it as the bearer of symbolic value derived from indigenous knowledge systems. As discussed earlier, the trader employs certain strategies to add to the value of the product. These strategies are described by Appadurai (in Huggan 2001, 31 ) as 'the politics of diversion and of display' (the spectacle of cultural difference, the discovery element) and 'the politics of authenticity and of authentication' (the construction of a native authenticity, the artificial aging of objects). The trader also relies on the 'politics of expertise and connoisseurship' (ethnic classification, reference to the authoritative book) and 'the politics of knowledge and ignorance' (story-telling): the tourist is not interested in accurate knowledge of the supposedly marginal cultural group, because that reduces the mystery surrounding the object. ${ }^{19}$ Exoticist myths are thus turned back on the Western consumer (Huggan 2001, x) to the trader's economic advantage. By recasting an ethnic aesthetic in the familiar mould of the 'authentic', the trader consciously reclaims African art from the Western connoisseur. While this exoticism is driven by financial gain, I would assert that it is an act of decolonising African art. It is an act of self-presentation by people subjected first to colonial domination and then to capitalist commoditisation. In support of the artist, the trader makes a conscious contribution to the preservation of African value systems. 


\section{Conclusion}

As co-authors of African tourist art, the artist and trader have reclaimed their cultural traditions, driven by pride in their African heritage and by the need for economic survival or profit. As Africans, the artist and trader capitalise on their ethnic identity, a primitivist aesthetic and indigenous tradition, to nurture the consumer's longing for the culturally different - something that is very fashionable in the globalised consumer market. While African tourist art is a sought-after commodity, it is, at the same time, capable of responding to the quest for postcolonial resistance. And that keeps it firmly locked in the sphere of the postcolonial exotic, that is, at the convergence of postcolonialism and postcoloniality, where the language of resistance is entangled in the language of commerce (ibid, 6).

By accepting tourist art as a product of the postcolonial exotic, it is possible to reposition it in a positive light. African tourist art has systematically been sidelined in art history because it would and could not conform to Western institutional thinking about art. Yet tourist art is no different from other categories of art: all art is supplied for the commodity market (Araeen 2002, 344). Thanks to the market, the African artist has an incentive to continue producing artworks in the tradition of the originating culture, and hence keep indigenous knowledge systems alive. Tourist art is successful as a commodity because its exoticism makes it accessible to the consumer. It therefore empowers the artists at village level and the middlemen to surmount the hardships that they face. By adapting to the global market, tourist art achieved what Mosquera considers to be the postcolonial challenge: ' ... to make traditions work within the new epoch' $(2002,269)$. Tourist art preserves tradition by making it work within the epoch of global consumerism.

\section{Notes}

1 The most significant contributions to this discourse were made by Paula Ben-Amos (1977), Nelson Graburn (2006), Bennetta Jules-Rosette (1984), Sidney Littlefield Kasfir (1999), and Christopher Steiner (1994).

2 Lawal (1990, 4-5) qualifies a given piece as traditional art if it retains the stylistic elements of the past 'as to make it identifiable with a specific ethnic group', if the artist belongs to that same group and was trained in the traditional manner, and if the piece was 'commissioned for use, and indeed used, in a traditional context' (original emphasis).

3 Another example is the tourist art of the Marquesas Islands, which developed from 1880 onwards, when the islanders started producing objects for trade/sale in forms unrelated to their own cultural tradition (Ivory 1999, 320 and 322).

4 Prioritising this cultural interaction, the term 'transcultural arts' was coined to denote 'arts that contact zones produce' (Phillips 1999, 33).

5 In line with this argument, the earliest examples of African tourist art are the BeninPortuguese ivories (sixteenth century) commissioned by Portuguese explorers and traders for export to Europe (Ben-Amos 1980, 27). 
6 Steiner $(1994,100)$ adds to this definition 'elements concerning an object's condition and history of use ... aesthetic merit, rarity, and estimated age'.

7 In response, Phillips (1999, 49-50) pleaded for ethno-historically framed studies: it is important to trace the history of an ethnic group and its art and to add a temporal dimension.

8 As early as 1926, the art critics Paul Guillaume and Thomas Munro noted that 'the coming of the white man has meant the passing of the negro artist; behind remains only an occasional uninspired craftsman dully imitating the art of his ancestors, chipping wood or ivory into a stiff, characterless image for the foreign trade' (in Steiner 1994, 104-105).

9 Huggan $(2001,6)$ refers to this condition as postcoloniality, a 'value-regulating mechanism' in which "value is constructed through global market operations involving the exchange of cultural commodities and, particularly, culturally "othered" goods'.

10 Steiner's study of African art in transit documents this process of commoditisation. He has 'explored the way in which objects are moved from one system of value to another, and described the mechanisms by which values are assigned to objects at each stage in the network of trade' $(1994,13)$.

11 For example, the nationalist strategy of constructing naturalised myths of racial or cultural origin in an effort to assert cultural tradition as an original claim to nationhood has been demonstrated by Van Robbroeck (2008) to be problematic for the middle-class black artist in South Africa.

12 It should be noted that in some rural villages, modernity had no profound impact on the community. The people sampled modernity, benefiting from the good things where possible, but they did not embrace it at the cost of their traditions (Kasfir 1999, 11).

13 For example, artists in Benin continue to produce queen mother heads, but in a more naturalistic style that transcends the traditional convention of stylised form (Nevadomsky 2005 , 74). This naturalism may be explained in the light of the globalisation of beauty standards (Okafor 2007, 37).

14 An art dealer from the DRC, trading at the African art market in Stellenbosch (personal interview, 4 September 2008), informed me that the Chinese are currently seen as posing an acute threat to the local production of African tourist art.

15 Bennetta Jules-Rosette $(2002,119)$ states that 'one of the distinguishing features of tourist art and a primary motivation for its commodification is its strong reliance on cultural brokers for the distribution and the modification of images'.

16 Although I held interviews with various African traders at different markets, I only make reference here to my experiences with Ervicks Ngatat as the most representative example.

17 See also Steiner $(1994,90-91)$. A specific ethnic identity is largely irrelevant to the trader (Steiner 1994, 89-90) and is only important in so far as it is perceived as a form of primitivism (Kasfir 1999a, 196).

18 In the case of Benin brass castings, Nevadomsky $(2005,76)$ confirms that Benin casters usually leave the antiquing to the middlemen.

19 Huggan $(2001,17,31)$. See also Cohodas $(1999,161)$, who maintains that the trader constructs 'the authenticating significations and relational values on which market valuation and ethnographic classification are often based'. 


\section{References}

Appadurai, A. 2006. Commodities and the politics of value. In The post-colonial reader, second edition, ed. B. Ashcroft, G. Griffiths and H. Tiffin, 417-420. London and New York: Routledge.

Araeen, R. 2002. A new beginning: Beyond postcolonial cultural theory and identity politics. In The third text reader on art, culture, and theory, ed. R. Araeen, S. Cubitt and Z. Sardar, 333-345. London and New York: Continuum.

Araeen, R., S. Cubitt and Z. Sardar, eds. 2002. The third text reader on art, culture, and theory. London and New York: Continuum.

Arnold, M., ed. 2008. Art in Eastern Africa. Dar es Salaam: Mkuki na Nyota Publishers.

Ashcroft, B., G. Griffiths and H. Tiffin, eds. 2006. The post-colonial reader, second edition. London and New York: Routledge.

Ben-Amos, P. 1977. Pidgin languages and tourist arts. Studies in the Anthropology of Visual Communication 4(2): 128-139.

. 1980. The art of Benin. London: Thames and Hudson.

Cohodas, M. 1999. Elizabeth Hickoz and Karuk basketry: A case study in debates on innovation and paradigms of authenticity. In Unpacking culture. Art and commodity in colonial and postcolonial worlds, ed. R.B. Phillips and C.B. Steiner, 143-161. Berkeley, C.A.: University of California Press.

Ettawageshik, F. 1999. My father's business. In Unpacking culture. Art and commodity in colonial and postcolonial worlds, ed. R.B. Phillips and C.B. Steiner, 20-29. Berkeley, C.A.: University of California Press.

Eze, E.C., ed. 1997. Postcolonial African philosophy: A critical reader. Oxford: Blackwell Publishers.

Fall, N. and J.L. Pivin, eds. 2002. An anthology of African art. The twentieth century. New York: Distributed Art Publishers; Paris: Revue Noire Éditions.

Graburn, N.H.H. 1999. Ethnic and tourist arts revisited. In Unpacking culture. Art and commodity in colonial and postcolonial worlds, ed. R.B. Phillips and C.B. Steiner, 335-353. Berkeley, C.A.: University of California Press.

2006. Arts of the Fourth World. In The anthropology of art: A reader, ed. H. Morphy and M. Perkins, 412-430. Malden, Oxford, Victoria: Blackwell Publishing.

Griffiths, G. 2006. The myth of authenticity. In The post-colonial reader, second edition, ed. B. Ashcroft, G. Griffiths and H. Tiffin, 165-168. London and New York: Routledge.

Huggan, G. 2001. The postcolonial exotic: Marketing the margins. London and New York: Routledge.

Ivory, C.S. 1999. Art, tourism and cultural revival in the Marquesas Islands. In Unpacking culture. Art and commodity in colonial and postcolonial worlds, ed. R.B. Phillips and C.B. Steiner, 316-333. Berkeley, C.A.: University of California Press.

Jules-Rosette, B. 1984. The messages of tourist art: An African semiotic system in comparative perspective. New York: Plenum Press.

. 2002. Representation and advertising: Airport art. In An anthology of African art. The twentieth century, ed. N. Fall and J.L. Pivin, 118-119. New York: Distributed Art Publishers; Paris: Revue Noire Éditions.

Kasfir, S.L. 1999a. Contemporary African art. London: Thames and Hudson. 
1999b. African art and authenticity: A text with a shadow. In Reading the contemporary: African art from theory to the marketplace, ed. O. Oguibe and O. Enwezor, 88-113. London: Institute of International Visual Arts.

. 1999c. Samburu souvenirs: Representations of a land in amber. In Unpacking culture. Art and commodity in colonial and postcolonial worlds, ed. R.B. Phillips and C.B. Steiner, 67-83. Berkeley, C.A.: University of California Press.

Lawal, B. 1990. The study of contemporary art in Nigeria: Towards a new theoretical framework. Paper presented at the $33^{\text {rd }}$ Annual Meeting of the African Studies Association, Baltimore, Maryland, 1-4 November, no. 45.

Lee, M. 1999. Tourism and taste cultures: Collecting native art in Alaska at the turn of the twentieth century. In Unpacking culture. Art and commodity in colonial and postcolonial worlds, ed. R.B. Phillips and C.B. Steiner, 267-281. Berkeley, C.A.: University of California Press.

Leiris, M. and J. Delange. 1967. Afrique Noire: La création plastique. Paris: Gallimard.

Makang, J-M. 1997. Of the good use of tradition: Keeping the critical perspective in African philosophy. In Postcolonial African philosophy: A critical reader, ed. E.C. Eze, 324-338. Oxford: Blackwell Publishers.

M'Bokolo, E. 2002. Rebirth and identities: The independence movements: A birth more than a rebirth. In An anthology of African art. The twentieth century, ed. N. Fall and J.L. Pivin, 216-218. New York: Distributed Art Publishers; Paris: Revue Noire Éditions.

Meyer, L. 1992. Black Africa. Masks, sculpture, jewelry. Paris: Terrail.

Morphy, H. and M. Perkins, eds. 2006. The anthropology of art: A reader. Malden, Oxford, Victoria: Blackwell Publishing.

Mosquera, G. 2002. The Marco Polo syndrome. In The third text reader on art, culture, and theory, ed. R. Araeen, S. Cubitt and Z. Sardar, 267-273. London and New York: Continuum.

Nevadomsky, J. 2005. Casting in contemporary Benin art. African Arts XXXVIII(2)(Summer): 66-77, 95.

Ngatat, E. 2008. Personal interview, 9 March 2008, Hatfield Market, Pretoria.

Oguibe, O. and O. Enwezor, eds. 1999. Reading the contemporary: African art from theory to the marketplace. London: Institute of International Visual Arts.

Okafor, C.G. 2007. Global encounters: 'Barbie' in Nigerian Agbogho-mmu mask context. Journal of African Cultural Studies 19(1): 37-54.

Phillips, R.B. 1999. Nuns, ladies and the 'Queen of the Huron': Appropriating the savage in nineteenth-century Huron tourist art. In Unpacking culture. Art and commodity in colonial and postcolonial worlds, ed. R.B. Phillips and C.B. Steiner, 33-50. Berkeley, C.A.: University of California Press.

Phillips, R.B. and C.B. Steiner, eds. 1999. Unpacking culture. Art and commodity in colonial and postcolonial worlds. Berkeley, C.A.: University of California Press.

. 1999. Art, authenticity and the baggage of cultural encounter. In Unpacking culture. Art and commodity in colonial and postcolonial worlds, ed. R.B. Phillips and C.B. Steiner, 3-19. Berkeley, C.A.: University of California Press.

Picton, J. 2002. A continent in the world: Tradition and the $20^{\text {th }}$ century. In An anthology of African art. The twentieth century, ed. N. Fall and J.L. Pivin, 324-333. New York: Distributed Art Publishers; Paris: Revue Noire Éditions. 
Schildkrout, E. 1999. Gender and sexuality in Mangbetu art. In Unpacking culture. Art and commodity in colonial and postcolonial worlds, ed. R.B. Phillips and C.B. Steiner, 197-213. Berkeley, C.A.: University of California Press.

Steiner, C. 1994. African art in transit. Cambridge: Cambridge University Press.

Van Robbroeck, L. 2008. Beyond the tradition/modernity dialectic. Cultural Studies 22(2):209233. http://dx.doi.org/10.1080/09502380701789117 